\title{
Ovarian oxytocin and the maternal recognition of pregnancy
}

\author{
A. P. F. Flint and E. L. Sheldrick \\ A.F.R.C. Institute of Animal Physiology, Babraham, Cambridge CB2 4AT, U.K.
}

\begin{abstract}
Summary. The secretion of oxytocin by the corpus luteum is thought to stimulate the episodic release of PGF- $2 \alpha$ from the uterus, thereby contributing to luteolysis. In pregnancy corpus luteum function is maintained, and secretion of oxytocin, or its actions on the uterus, appear to be inconsistent with the successful establishment of gestation. Protection against the effects of oxytocin is ensured by a number of mechanisms, including the cessation of luteal oxytocin secretion, which is evident by Day 20 after mating in sheep, and the maintenance of low levels of the oxytocin receptor in the uterus.
\end{abstract}

\section{Introduction}

That oxytocin is involved in reproductive processes other than lactation and the expulsive phase of labour was indicated first by the demonstration that systemic administration of large doses of oxytocin shortens the oestrous cycle in heifers (Armstrong \& Hansel, 1959). This effect was observed when oxytocin was given early in the oestrous cycle, and was blocked by hysterectomy. It also occurs in sheep (Milne, 1963; Dobrowolski, 1973; Hatjiminaoglou, Alifakiotis \& Zervas, 1979) and goats (Cooke \& Knifton, 1981). The concept that oxytocin plays a role in oestrous cyclicity was further supported by the observation that oxytocin stimulates uterine secretion of the luteolysin, prostaglandin (PG) F-2 $\alpha$ (Sharma \& Fitzpatrick, 1974; Mitchell, Flint \& Turnbull, 1975; Roberts, McCracken, Gavagan \& Soloff, 1976), and by the finding that uterine concentrations of the oxytocin receptor increase at the end of the oestrous cycle (Roberts et al., 1976; Sheldrick \& Flint, 1985a).

The report that oxytocin-neurophysin is released in episodes synchronously with PGF-2 $\alpha$ at the time of luteal regression (Fairclough et al., 1980) provided the first indication that endogenous oxytocin might have a physiological role in controlling the oestrous cycle, and this was supported by the delay of luteal regression observed in sheep immunized against oxytocin (Sheldrick, Mitchell \& Flint, 1980; Schams, Prokopp \& Barth, 1983). Shortly after these observations it was shown that concentrations of oxytocin in the peripheral circulation rose and fell in parallel to those of progesterone (Webb, Mitchell, Falconer \& Robinson, 1981; Sheldrick \& Flint, 1981; Schams, Lahlou-Kassi \& Glatzel, 1982), and this led to the observation that the corpus luteum contained (Wathes \& Swann, 1982; Flint \& Sheldrick, 1982a) and secreted (Flint \& Sheldrick, 1982b) large quantities of the peptide. The conclusion that the corpus luteum contained oxytocin was in fact predated by some 60 years by the report that the corpus luteum contained a substance capable of inducing milk let-down in goats (Ott \& Scott, 1910).

The demonstration that the corpus luteum secretes oxytocin raises several important questions in relation to the endocrine control of the uterus early in gestation. Oxytocin clearly has effects on the endometrium and the myometrium under certain conditions, causing the former to synthesize and secrete prostaglandins, and the latter to contract. Both of these effects may be considered inconsistent with the establishment of pregnancy; although some uterine secretion of prostaglandins, particularly PGE-2, may be a characteristic of early gestation, uterine secretion of 
PGF- $2 \alpha$ would result in luteal regression, causing the withdrawal of progesterone, the steroid principally involved in maintaining secretion by endometrial glands. Similarly, although some uterine contractility may be required to bring about the spacing of blastocysts through the uterine lumen, an excessive stimulation of myometrial activity might expel the blastocysts from the uterus. The question therefore arises, how is the action of oxytocin on the uterus prevented, when it is secreted by an organ which simultaneously provides the endocrine support necessary for the uterus to sustain the developing embryo? The answer appears to lie in a number of characteristic adaptations to pregnancy at the level both of the corpus luteum and the uterus. Since most of the experimental work in this area has been conducted with ruminants, in which the corpus luteum is a particularly important source of oxytocin, and in which the relatively long preimplantation phase of embryonic growth necessitates sustenance of the conceptus by uterine secretions, this review will deal with these questions principally as they apply to sheep and cattle.

\section{Identification of luteal oxytocin}

Until recently, oxytocin of luteal origin had been identified most frequently on the basis of its cross-reaction in radioimmunoassays, elution on high performance liquid chromatography and in bioassays (see Flint \& Sheldrick, 1985). Since there are many related and biologically active neurohypophysial hormones which cross-react to various extents in all radioimmunoassays for oxytocin, this raised the possibility that the ovarian peptide is not in fact oxytocin.

There are now, however, two pieces of evidence which, taken together, strongly indicate that the luteal peptide has the same structure as oxytocin; these are firstly, that fast-atom bombardment mass spectrometry has been used to determine the molecular mass of the luteal compound purified by high performance liquid chromatography (Figs 1 and 2; Flint \& Sheldrick, 1985), and, secondly, that the messenger RNA for the oxytocin-neurophysin prohormone from bovine corpora lutea has been cloned in the form of complementary DNA and sequenced (Ivell \& Richter, 1984). It is important to take these pieces of evidence together because it is possible that, although the prohormone is identical in the ovary and neurohypophysis, it undergoes post-translational processing in the corpus luteum to yield a compound distinct from that in the brain. That the molecular mass of the peptide from the two sources is identical precludes any such occurrence.

The finding that the oxytocin-neurophysin prohormone of luteal origin is identical to that in the neurohypophysis is consistent with reports of the secretion of the neurophysin simultaneously with PGF-2 $\alpha$ (Fairclough et al., 1980; Flint \& Sheldrick, 1983). Since both oxytocin and the neurophysin are synthesized from the same prohormone, one would expect them to be secreted in a 1:1 molar stoichiometry and this has in fact been demonstrated in animals in which arterio-venous concentration differences were measured across the ovary for both compounds (Watkins, Moore, Flint \& Sheldrick, 1984).

Fig. 1. HPLC and fast-atom bombardment mass spectrometry of luteal oxytocin. Oxytocin was purified from corpora lutea of cyclic ewes using thin layer chromatography and Sep-Pak adsorption (Flint \& Sheldrick, 1985) before application to HPLC. Three successive HPLC purifications are shown: (a) on $\mu$-Bondapak radial compression cartridge with gradient elution;

(b) Radial Pak cartridge with isocratic elution: (c) $\mu$-Bondapak cartridge as (a). Material from

(a) was purified as in (b) followed by (c), before application to FAB/MS. OT = oxytocin; IT = isotocin; $\quad$ AVT $=$ arginine vasotocin; $\quad$ LVP = lysine vasopressin; $A V P=$ arginine vasopressin; $\mathbf{M T}=$ mesotocin. 

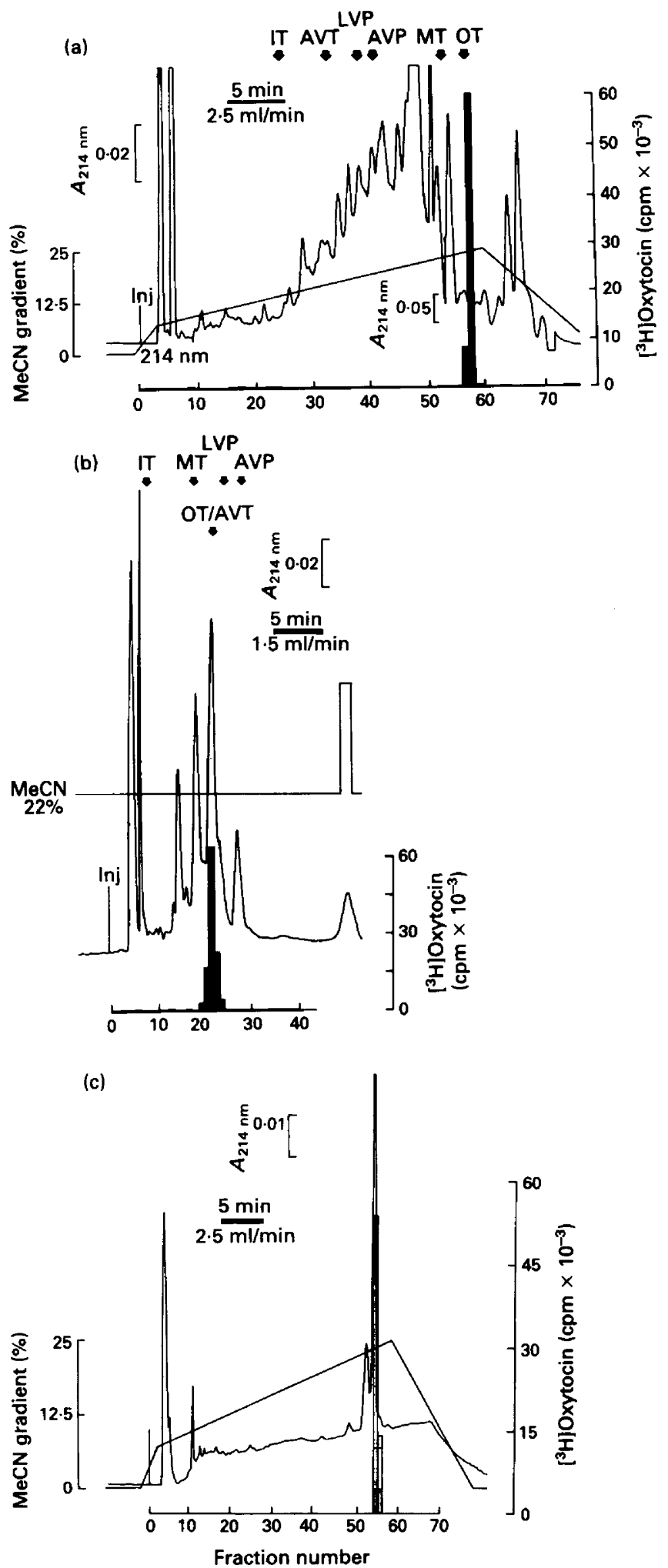


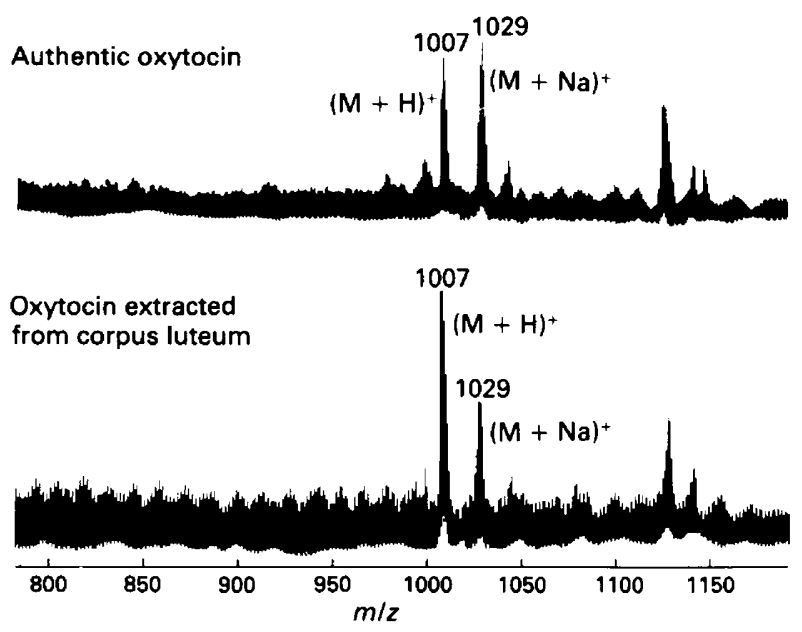

Fig. 2. Fast-atom bombardment mass spectrometry trace indicates molecular ions with molecular weights of $1007(\mathrm{M}+\mathrm{H})^{+}$and $1029(\mathrm{M}+\mathrm{Na})^{+}$. (Mol. wt oxytocin is 1006.)

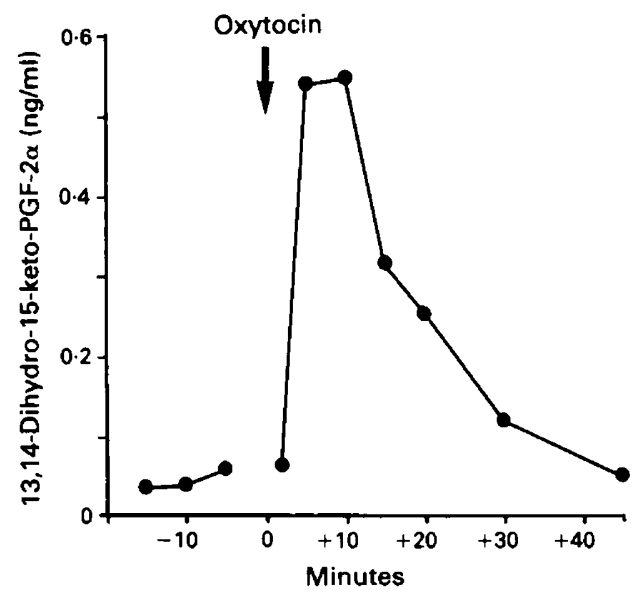

Fig. 3. Effect of oxytocin $(1 \mu \mathrm{g})$ administered as a bolus injection intravenously in one ewe. The animal had been treated with medroxyprogesterone acetate (Veramix intravaginal sponge; Upjohn Ltd) for 11 days followed by oestradiol-17ß $(100 \mu \mathrm{g} / \mathrm{day}$ for 2 days). The 13,14-dihydro-15-ketoprostaglandin F-2 $\alpha$ (major pulmonary metabolite of PGF-2 $\alpha$ ) was measured in jugular venous plasma by radioimmunoassay.

\section{Functions of luteal oxytocin}

One of the most intriguing aspects of the effects of oxytocin is that the actions of the circulating hormone appear to be controlled to a great extent by concentrations of its receptor on target tissue cells. Thus the myometrium and the mammary gland which are sensitive to oxytocin of neurohypophysial origin during labour and lactation, respectively, are relatively insensitive at other times. A similar change in uterine sensitivity to oxytocin occurs during the oestrous cycle in sheep, but in this case the target organ appears to be principally the endometrium, rather than the myometrium, and the action of oxytocin is to cause the endometrium to secrete prostaglandins (Fig. 3). The sensitivity of the uterus to oxytocin in terms of prostaglandin secretion is greatest close 


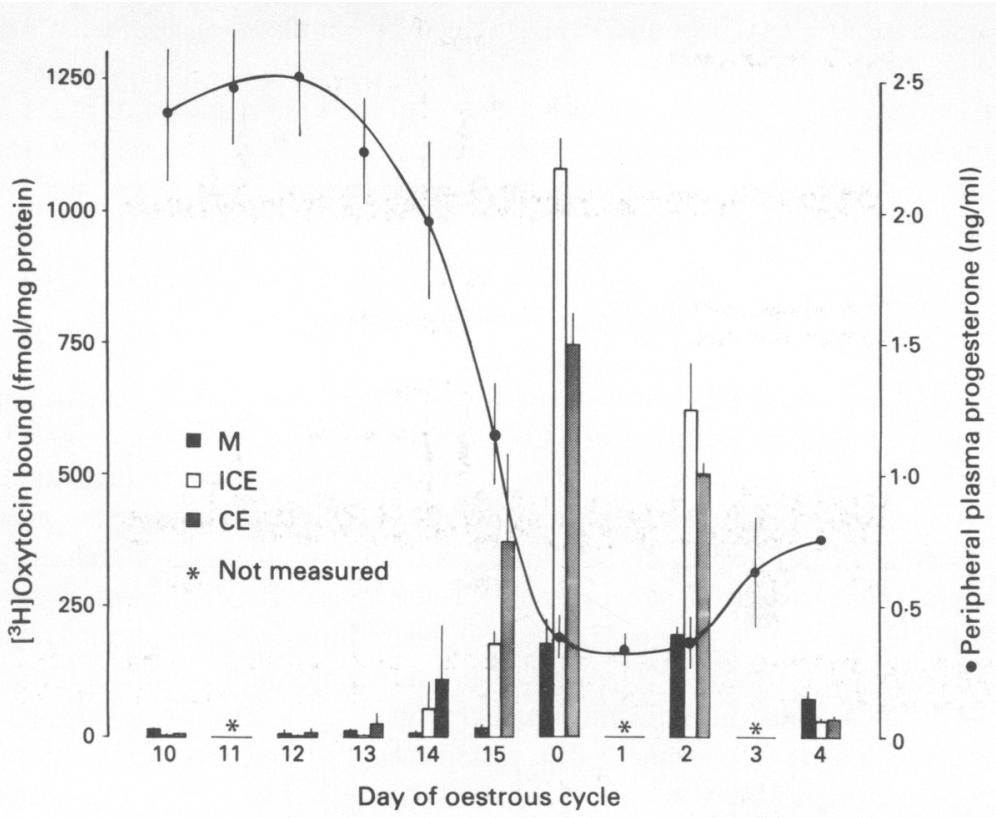

Fig. 4. Uterine oxytocin receptors during the oestrous cycle in ewes. Receptor concentrations were determined using $\left[3,5-{ }^{3} \mathrm{H}-\mathrm{Tyr}\right]$ oxytocin (sp. act. $27 \mathrm{Ci} / \mathrm{mmol}$ ) followed by Millipore filtration. Measurements were made in caruncular endometrium (CE), intercaruncular endometrium (ICE) and myometrium (M) and are for 2 ewes on each day. Progesterone concentrations were determined in the peripheral circulation in the same animals. (After Sheldrick \& Flint, 1985a.)

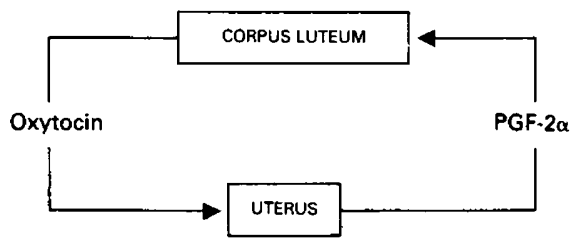

Fig. 5. Positive-feedback loop showing possible interrelationship between corpus luteum and uterus.

to oestrus (Roberts et al., 1976), and this is the time when endometrial oxytocin receptor concentrations peak (Roberts et al., 1976; Sheldrick \& Flint, 1985a; Fig. 4). Furthermore, the caruncular endometrium, which produces prostaglandins in vitro at a higher rate than the intercaruncular endometrium (Findlay et al., 1981), has the higher receptor concentration of the two endometrial compartments.

Because of the ability of oxytocin to stimulate endometrial PGF-2 $\alpha$ secretion (Sharma \& Fitzpatrick, 1974; Roberts et al., 1976), and of PGF-2 $\alpha$ to stimulate luteal secretion of oxytocin (Flint \& Sheldrick, 1982b), the suggestion has been made that the secretion of these two compounds may be linked by a positive feedback loop of the kind illustrated in Fig. 5 (Flint \& Sheldrick, 1983). Such a mechanism of mutual stimulation will clearly only operate when both organs are sensitive to their respective stimulants; although the corpus luteum will respond to PGF-2 $\alpha$ throughout the luteal phase of the cycle, this may not be true of the response of the endometrium to oxytocin, as indicated in Fig. 4. None the less there is evidence for the operation of such 
a loop because secretion of oxytocin and PGF-2 $\alpha$ occur in simultaneous pulses at luteal regression (Fairclough et al., 1980; Flint \& Sheldrick, 1983).

It has been suggested that a positive-feedback loop of the kind depicted in Fig. 5 might account for the pulsatile nature of the secretion of both oxytocin and PGF- $2 \alpha$ (Flint \& Sheldrick, 1983, 1985). However, an alternative hypothesis, based on receptor occupancy, has been proposed (McCracken, Schramm \& Okulicz, 1984).

\section{Oxytocin in early pregnancy}

Given the truth of the premise proposed in the 'Introduction', that the successful establishment of pregnancy is compromised by secretion of PGF-2 $\alpha$ and oxytocin, one would expect there to exist mechanisms by which these processes would be inhibited in pregnancy. In fact, there appear to be several such mechanisms, which can be seen as acting at different points in the positive-feedback loop (Fig. 5). Firstly, the developing conceptus secretes an antiluteolysin, which in sheep is known to be the protein ovine trophoblastic protein 1 (oTP-1: see Bazer, Vallet, Roberts, Sharp \& Thatcher, 1986). This protein is secreted by the trophectoderm between about Days 12 and 22 of gestation in sheep, and it is thought to act (by an unknown mechanism) by inhibiting endometrial PGF- $2 \alpha$ synthesis. A second mechanism, which involves an alteration in uterine sensitivity to oxytocin, consists of a drop in endometrial oxytocin receptor concentrations, relative to the nonpregnant state at a comparable time after oestrus (Table 1). The rise in receptor concentration observed shortly before, and during, oestrus in cyclic animals, is therefore absent in pregnancy (Sheldrick \& Flint, 1985a). Whether this results from the process of luteal maintenance, or is one of its causes, is at present unclear.

A third adaptation to pregnancy involves the cessation of luteal secretion of oxytocin (Sheldrick \& Flint, 1983a). Concentrations of oxytocin in corpora lutea analysed between Days 20 and 147 of gestation are below $20 \mathrm{ng} / \mathrm{g}$ wet weight, or about $1.0 \%$ of peak levels reached in non-pregnant animals (Fig. 6). This effect appears to result from the prolongation of the life-span of the corpus luteum since it can be mimicked by hysterectomy (Sheldrick \& Flint, 1983b), or by immunizing ewes against PGF-2 $\alpha$ or oxytocin (Sheldrick \& Flint, 1985b). The loss of oxytocin from the corpus

Table 1. Uterine concentrations of oxytocin receptor in pregnant and nonpregnant ewes

\begin{tabular}{|c|c|c|c|c|}
\hline & \multirow[b]{2}{*}{$\begin{array}{l}\text { No. of } \\
\text { ewes }\end{array}$} & \multicolumn{3}{|c|}{$\begin{array}{l}\text { Mean conc. oxytocin receptor } \\
\text { (fmol/mg protein) in: }\end{array}$} \\
\hline & & $\begin{array}{l}\text { Caruncular } \\
\text { endometrium }\end{array}$ & $\begin{array}{l}\text { Intercaruncular } \\
\text { endometrium }\end{array}$ & Myometrium \\
\hline \multicolumn{5}{|c|}{ Non-pregnant } \\
\hline Day 12 & 2 & 10 & 1 & 9 \\
\hline Day 13 & 2 & 26 & 1 & 12 \\
\hline Day 14 & 2 & 109 & 55 & 8 \\
\hline Day 15 & 2 & 373 & 179 & 19 \\
\hline Oestrus & 2 & 750 & 1085 & 179 \\
\hline Day 2 & 2 & 505 & 624 & 197 \\
\hline Day 4 & 2 & 35 & 31 & 73 \\
\hline \multicolumn{5}{|l|}{ Pregnant } \\
\hline Day 14 & 2 & 10 & 9 & 8 \\
\hline Day 15 & 1 & N.D. & 14 & 10 \\
\hline Day 17 & 2 & 6 & 8 & 11 \\
\hline Day 19 & 2 & 3 & 9 & 12 \\
\hline
\end{tabular}

N.D. = not detectable. 


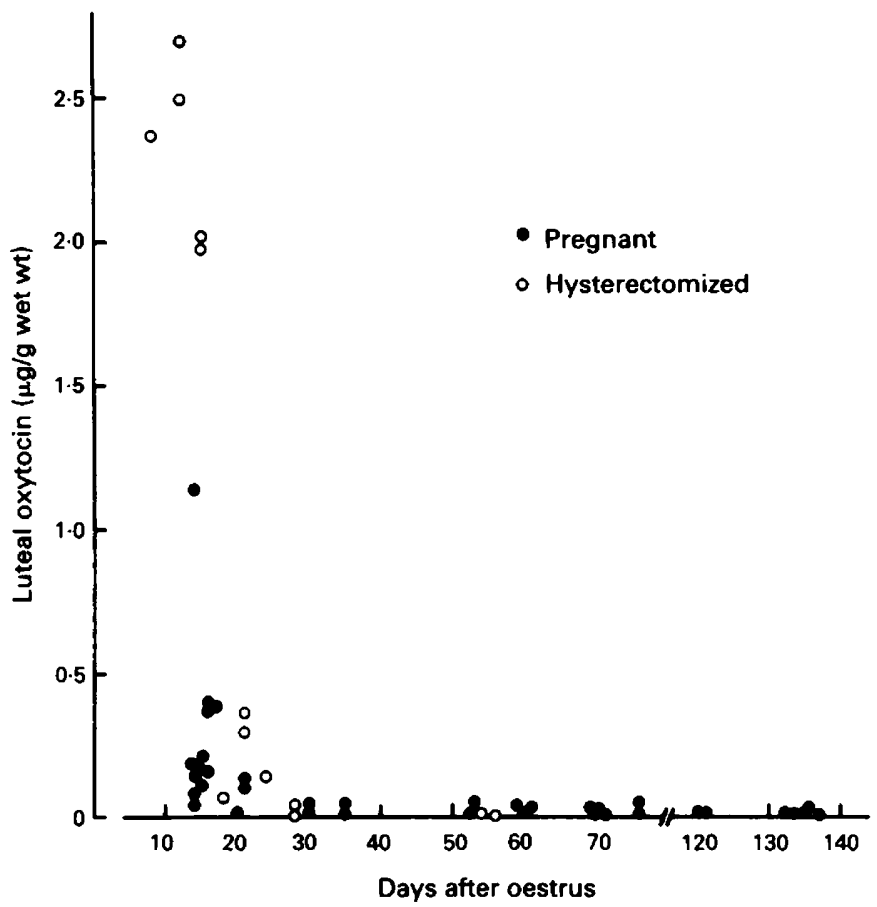

Fig. 6. Luteal concentrations of oxytocin during early pregnancy and after hysterectomy in sheep. Hysterectomy was performed on Day 6 after oestrus.

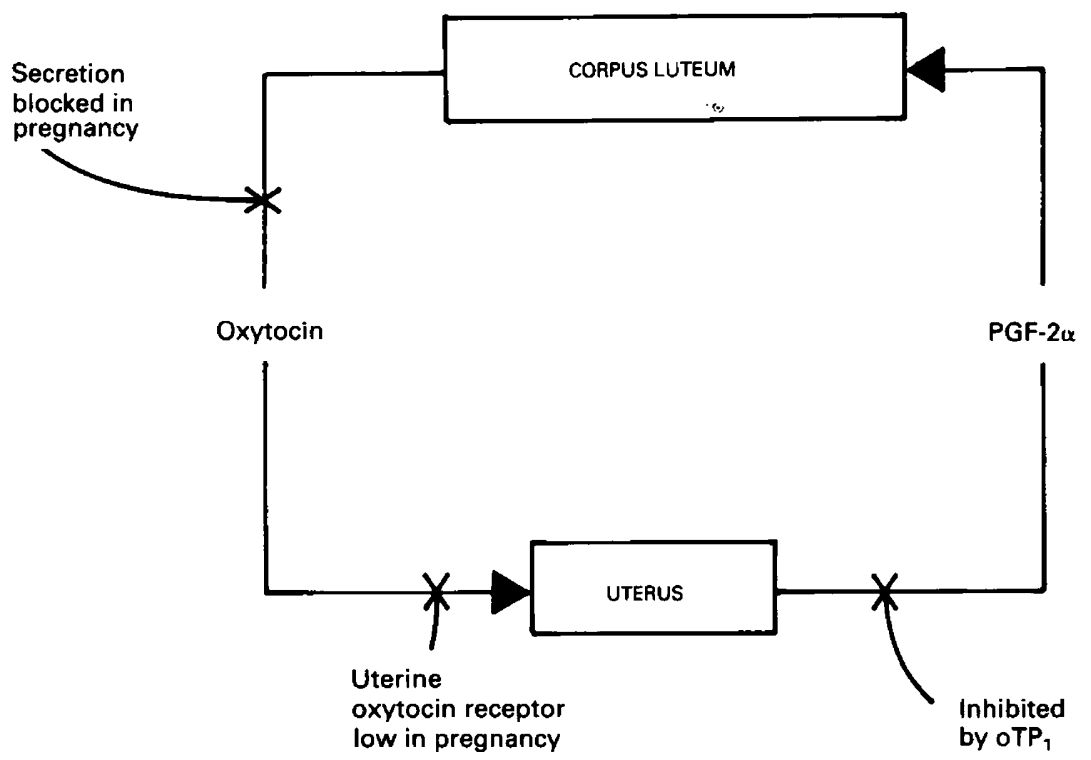

Fig. 7. Adaptation of the postulated positive-feedback relationship between oxytocin and PGF- $2 a$ to pregnancy in sheep. $\mathrm{OTP}_{1}=$ ovine trophoblast protein 1 . 
luteum is reflected in a reduced circulating concentration of oxytocin on Days 14 and 15 of gestation (Sheldrick \& Flint, 1983a; Schams \& Lahlou-Kassi, 1984). Although these reports differ in that the data of Sheldrick \& Flint (1983a) suggest there may be a transient rise in circulating levels between Days 16 and 20, which is absent in the data of Schams \& Lahlou-Kassi (1984), and may be the result of use of a less specific antibody, there is little doubt that for the major part of gestation, after Day 20, circulating concentrations of oxytocin are low.

\section{Conclusion}

These mechanisms controlling luteal function and uterine contractility in early gestation, which can be viewed as forming an interrelated series of functions, are summarized in Fig. 7. The time at which luteal oxytocin is lost coincides closely with that at which the conceptus stops producing the antiluteolysin, and it has been suggested (Sheldrick \& Flint, 1983a) that the latter is accommodated as a result of the former; that is, there ceases to be a need to produce the antiluteolysin after luteal oxytocin is lost, because in the absence of oxytocin the uterus is unable to mount an episode of PGF- $2 \alpha$ secretion.

\section{References}

Armstrong, D.T. \& Hansel, W. (1959) Alteration of the bovine estrous cycle with oxytocin. J. Dairy Sci. 42, 533-542.

Bazer, F.W., Vallet, J.L., Roberts, R.M., Sharp, D.C. \& Thatcher, W.W. (1986) Role of conceptus secretory products in establishment of pregnancy. J. Reprod. Fert. 76, 841-850.

Cooke, R.G. \& Knifton, A. (1981) Oxytocin-induced oestrus in the goat. Theriogenology 16,95-97.

Dobrowolski, W. (1973) Wplyw oksytocyny na cykl plciowy owcy w sezonie rozplodu i ciszy seksualnej. Polsk. Archiwum Wet. 16, 649-654.

Fairclough, R.J., Moore, L.G., McGowan, L.T., Peterson, A.J., Smith, J.F., Tervit, H.R. \& Watkins, W.B. (1980) Temporal relationship between plasma concentrations of 13,14-dihydro-15-keto-prostaglandin $\mathrm{F}$ and neurophysin $\mathrm{I} / \mathrm{II}$ around luteolysis in sheep. Prostaglandins 20, 199-208.

Findlay, J.K., Ackland, N., Burton, R.D., Davis, A.J., Maule Walker, F.M., Walters, D.E. \& Heap, R.B. (1981) Protein, prostaglandin and steroid synthesis in caruncular and intercaruncular endometrium of sheep before implantation. J. Reprod. Fert. 62, 361-377.

Flint, A.P.F. \& Sheldrick, E.L. (1982a) Ovarian secretion of oxytocin in the sheep. J. Physiol., Lond. 330, $61 P-62 P$, Abstr.

Flint, A.P.F. \& Sheldrick, E.L. (1982b) Ovarian secretion of oxytocin is stimulated by prostaglandin. Nature, Lond. 297, 587-588.

Flint, A.P.F. \& Sheldrick, E.L. (1983) Evidence for a systemic role for ovarian oxytocin in luteal regression in sheep. J. Reprod. Fert. 67, 215-225.

Flint, A.P.F. \& Sheldrick, E.L. (1985) Ovarian oxytocin. In Oxytocin: Clinical and Laboratory Studies, pp. 335-350. Eds J. A. Amico \& A. G. Robinson. Elsevier Science Publishers, Amsterdam.
Hatjiminaoglou, I., Alifakiotis, T. \& Zervas, N. (1979) The effect of exogenous oxytocin on estrous cycle length and corpus luteum lysis in ewes. Annls Biol. anim. Biochim. Biophys. 19, 355-365.

Ivell, R. \& Richter, D. (1984) The gene for the hypothalamic peptide hormone oxytocin is highly expressed in the bovine corpus luteum: biosynthesis, structure and sequence analysis. The EMBO Journal 3, 2351-2354.

McCracken, J.A., Schramm, W. \& Okulicz, W.C. (1984) Hormone receptor control of pulsatile secretion of $\mathrm{PGF}_{2 a}$ from the ovine uterus during luteolysis and its abrogation in early pregnancy. Anim. Reprod. Sci. 7, 31-55.

Milne, J.A. (1963) Effects of oxytocin on the oestrous cycle of the ewe. Aust. vet. J. 39, 51-52.

Mitchell, M.D., Flint, A.P.F. \& Turnbull, A.C. (1975) Stimulation by oxytocin of prostaglandin $F$ levels in uterine venous effluent in pregnant and puerperal sheep. Prostaglandins 9, 47-56.

Ott, I. \& Scott, J.C. (1910) The galactogogue action of the thymus and corpus luteum. Proc. Soc. exp. Biol. Med. 8, 49.

Roberts, J.S., McCracken, J.A., Gavagan, J.E. \& Soloff, M.S. (1976) Oxytocin-stimulated release of prostaglandin $\mathrm{F}_{2 \mathrm{a}}$ from ovine endometrium in vitro: correlation with estrous cycle and oxytocin-receptor binding. Endocrinology 99, 1107-1114.

Schams, D. \& Lahlou-Kassi, A. (1984) Circulating concentrations of oxytocin during pregnancy in ewes. Acta endocr., Copenh. 106, 277-281.

Schams, D., Lahlou-Kassi, A. \& Glatzel, P. (1982) Oxytocin concentrations in peripheral blood during the oestrous cycle and after ovariectomy in two breeds of sheep with low and high fecundity. J. Endocr. 92, 9-13.

Schams, D., Prokopp, S. \& Barth, D. (1983) The effect of 
active and passive immunization against oxytocin on ovarian cyclicity in ewes. Acta endocr., Copenh. 103, 337-344.

Sharma, S.C. \& Fitzpatrick, R.J. (1974) Effect of oestradiol-17 $\beta$ and oxytocin treatment on $\mathrm{PGF}_{\mathrm{a}}$ release in the anoestrous ewe. Prostaglandins 6, 97-105.

Sheldrick, E.L. \& Flint, A.P.F. (1981) Circulating concentrations of oxytocin during the estrous cycle and early pregnancy in sheep. Prostaglandins 22, 631-636.

Sheldrick, E.L. \& Flint, A.P.F. (1983a) Luteal concentrations of oxytocin decline during early pregnancy in the ewe. J. Reprod. Fert. 68, 477-480.

Sheldrick, E.L. \& Flint, A.P.F. (1983b) Regression of the corpora lutea in sheep in response to cloprostenol is not affected by loss of luteal oxytocin after hysterectomy. J. Reprod. Fert. 68, 155-160.

Sheldrick, E.L. \& Flint, A.P.F. (1985a) Endocrine control of uterine oxytocin receptors in the ewe. $J$. Endocr. 106, 249-258.
Sheldrick, E.L. \& Flint, A.P.F. (1985b) Ovarian oxytocin. In Gonadal Proteins and Peptides and Their Biological Significance, pp. 257-272. Eds M. R. Sairam \& L. E. Atkinson. World Scientific Publishing, Singapore.

Sheldrick, E.L., Mitchell, M.D. \& Flint, A.P.F. (1980) Delayed luteal regression in ewes immunized against oxytocin. J. Reprod. Fert. 59, 37-42.

Wathes, D.C. \& Swann, R.W. (1982) Is oxytocin an ovarian hormone? Nature, Lond. 297, 225-227.

Watkins, W.H., Moore, L.G., Flint, A.P.F. \& Sheldrick, E.L. (1984) Secretion of neurophysins by the ovary in sheep. Peptides 5, 61-64.

Webb, R., Mitchell, M.D., Falconer, J. \& Robinson, J.S. (1981) Temporal relationships between peripheral plasma concentrations of oxytocin, progesterone and 13,14-dihydro-15-keto prostaglandin $F_{2 a}$ during the estrous cycle and early pregnancy in the ewe. Prostaglandins 22, 443-453. 